\title{
Selective Determination of V(IV) and V(V) in Seawater by Solid Phase Extraction and Electrothermal Atomic Absorption Spectrometry
}

\author{
L. Alcalde-Isorna, M.C. Barciela-Alonso, and P. Bermejo-Barrera* \\ Department of Analytical Chemistry, Nutrition and Bromatology. \\ University of Santiago de Compostela, E-15782 Santiago de Compostela, Spain
}

\section{INTRODUCTION}

Vanadium is usually present in the environment at low concentrations, but the levels can be increased in certain areas due to emission from different processes such as the metallurgical industry or the manufacture of corrosionresistant alloys $(1,2)$. The typical seawater concentration is in the $30-50 \mathrm{nM}$ range (3), and the concentration in river water is around $15 \mathrm{nM}$ (4). The dissolved vanadium concentrations reported for the Galician coast seawater samples are between 18-35 nM (5).

Vanadium (V) is considered an essential trace element at low concentration levels (0.2-29.0 $\mu \mathrm{g} \mathrm{L}^{-1}$ in water) and is beneficial for normal cell growth (6). However, at high concentrations ( $\mathrm{mg} \mathrm{L}^{-1}$ levels) it is toxic and results in carcinogenic effects and produces damage to liver and kidney (7). The toxicity of vanadium depends not only on its concentration but also on its chemical form. It can exist in fresh water and seawater as V(IV) and V(V), the latter being the most toxic form $(8,9)$. Due to their toxicity properties, the determination of the concentration of each species is extremely important.

\section{Fresh Water Sample Analysis}

Several methods have been reported in the literature for vanadium speciation. Nakano et al. (10) reported the fractional determination of V(IV) and V(V) in fresh water using a catalytic method

\footnotetext{
* Corresponding author.

E-mail: pilar.bermejo@usc.es
}

\begin{abstract}
A selective and sensitive method was developed for the separation and preconcentration of V(IV) and V(V) from seawater samples using a Chelex ${ }^{\circledR}-100$ column. The influence of different parameters in the separation procedure such as $\mathrm{pH}$ of the sample, volume and concentration of extracting agents $\left[\mathrm{NH}_{3}\right.$ for $\mathrm{V}(\mathrm{V})$ and $\mathrm{HNO}_{3}$ for $\mathrm{V}(\mathrm{IV})$ ], sample load flow rate and the eluting flow rate were studied. The separated species were then determined by electrothermal atomic absorption spectrometry (ETAAS).

The limits of detection (LODs) and limits of quantification (LOQs) obtained using $50 \mathrm{~mL}$ of a seawater sample were 0.15 and $0.50 \mu \mathrm{gL}^{-1}$, respectively, for $\mathrm{V}(\mathrm{IV})$ and 0.10 and $0.33 \mu \mathrm{gL}^{-1}$ respectively, for $\mathrm{V}(\mathrm{V})$. The recovery percentages were $95.3 \pm 3 \%$ and $92.3 \pm 3 \%$ for V(IV) and $\mathrm{V}(\mathrm{V})$, respectively. The method was applied to the V(IV) and $\mathrm{V}(\mathrm{V})$ determination in seawater samples from the Galician coast. The only species detected in the three samples studied was V(V), which is the most toxic form and was found in concentration levels ranging from 0.1 to $0.25 \mu \mathrm{g} \mathrm{L}^{-1}$. The method is simple, quick, and low cost.
\end{abstract}

combined with the solvent extraction N-cinnamoyl-N-(2,3-xylyl) hydroxylamine (CXA). Okamura et al. (11) developed an automated method for the determination of vanadium (IV) and (V) in fresh water based on chelating resin separation and catalytic detection with Bindschedler's green leuco base. Chia-Ching Wann et al. (12) deter- mined vanadium species in water samples by liquid chromatography coupled with plasma mass spectrometry and using a silicabased $\mathrm{CRC}_{8}$ reversed-phase column. Soldi et al. (13) studied the mechanism of V(V) and V(IV) separation by sorption on an iminodiacetic chelating resin (Chelex $\left.{ }^{\circledR}-100\right)$. These authors proposed the sorption of both species at a $\mathrm{pH}$ of approximately 4.5 and separating them by sequentially stripping V(V) at a $\mathrm{pH}$ of approximately 10 and then $\mathrm{V}(\mathrm{IV})$ at a $\mathrm{pH}$ of approximately 0.8 . Based on this work, Deli Wang et al. (14) further developed an analytical protocol for the determination of V(IV) and V(V) in seawater samples. These authors used a solidphase extraction of both species at pH 4.5 with Chelex-100, followed by the elution of $\mathrm{V}(\mathrm{V})$ with $0.1 \mathrm{M}$ ammonium hydroxide and the elution of V(IV) with $0.2 \mathrm{~N}$ perchloric acid. The species eluted were dried on a hot plate and re-dissolved in $2 \mathrm{~mL}$ of $0.1 \mathrm{~N} \mathrm{HNO}_{3}$. The quantification of both vanadium species was performed by ETAAS. Amberlite XAD-7 (15) has also been used for the speciation and preconcentration of vanadium species from water samples by flow injectioninductively coupled plasma optical emission spectrometry (FI-ICPOES). Vanadium was retained on the resin in the form of $\mathrm{V}-(5-\mathrm{Br}$ PADAP) complex, and 1,2-ciclohexanediamine-tetraacetic acid (CDTA) was used as masking agent for V(IV). The concentration of V(IV) was calculated by the difference between the total concentration of $\mathrm{V}$ and V(V). Hayati Filik et al. (16) reported a method for the simultaneous preconcentration of vanadium (V/IV) species with 
palmitoyl quinolin-8-ol bonded to Amberlite XAD-2 prior to simultaneous speciation analysis. The preconcentrated species were then quantitatively eluted from the resin column using $\mathrm{HCl}$ as the stripping agent. Total vanadium concentration was determined in the eluted fraction using 4-(2-pyridylazo)-resorcinol (PAR) by spectrophotometric detection at $542 \mathrm{~nm}$. Vanadate was then quantified by masking vanadyl with 1,2 cyclohexanediaminetetraacetic acid (CDTA).

\section{Seawater Sample Analysis}

In the method developed by Nukatsuka et al. (17), V(IV) was extracted from seawater samples as metal complexes with Chromazurol $\mathrm{B}(\mathrm{CAB})$ using the suspension of an anion-exchange resin. V(V) was extracted in the same way but using N-cinamoyl-N-2,3-xylylhydroxylamine (CXA) as the extracting agent. The species were then determined in the suspension by ETAAS. ZuLiang Chen et al. (18) developed an on-column complexation method for the simultaneous determination of V(IV) and V(V) in groundwater. The vanadium species were chelated with ammonium polycarboxylic acid to form anionic complexes, which were separated by capillary zone electrophoresis and determined using direct ultraviolet (UV) detection.

\section{Proposed Method}

In this work, a method for V(IV/V) separation and preconcentration using a Chelex-100 column and determination by ETAAS was developed. This method is based on the previous study developed by Soldi et al. (13) for V(IV/V) separation using a Chelex-100 column and eluting V(V) at basic pH (with ammonia) and V(IV) in an acid $\mathrm{pH}$ (with perchloric acid). The method was applied to the determination of these vanadium species in seawater samples from the Galician coast (Northwestern Spain).

\section{EXPERIMENTAL}

\section{Instrumentation}

Measurements were performed using a PerkinElmer ${ }^{\circledR}$ Model 1100B atomic absorption spectrometer (PerkinElmer, Inc., Shelton, CT, USA), equipped with an HGA ${ }^{\circledR}-700$ graphite furnace atomizer and an AS-40 autosampler. The source of radiation was a vanadium hollow cathode lamp (Cathodeon, Cambridge, UK). Pyrolytically coated graphite tubes with L'vov platforms were used for the analysis. For all measurements made during this study, integrated absorbance was used with an integration time of six seconds. The temperature and time programs for the atomizer and the instrumental parameters are listed in Table I. The sample volume injected was $20 \mu \mathrm{L}$.

A Rheodyne ${ }^{\circledR}$ Model 7060RV, 6 Position/6 Port standard valve (Bensheim, Germany) and a Model Minipuls $^{\text {TM }}-3$ peristaltic pump (Gilson, Villiers le Bel, France) were used in the vanadium separation and preconcentration step. The sample $\mathrm{pH}$ was measured with a Thermo Orion Model $720 \mathrm{pH}$ meter (Thermo Orion, Bevery, MA, USA). Other instrumentation used during sample preparation included a Sartorius Model BP121S analytical balance (Sartorius, Goettingen, Germany), a polytetrafluoroethylene (PTFE) column $(5 \mathrm{~cm}$ length,

\section{Atomic Apectroscopy \\ 1 Vol. 32(6), Nov./Dec. 2011}

$3 \mathrm{~mm}$ i.d.), and polyethylene (PE) tubing and connectors from Gilson, France, S.A. and PerkinElmer, Inc..

\section{Standard Solutions and Reagents}

The stock standard solutions of $1000 \mathrm{mg} \mathrm{L}^{-1}$ vanadium (V), $\left(\mathrm{NH}_{4} \mathrm{VO}_{3}\right.$ in $\left.\mathrm{HNO}_{3} 0.5 \mathrm{M}\right)$, and vanadium (IV), $\mathrm{VOSO}_{4}$ in $8.6 \% \mathrm{H}_{2} \mathrm{SO}_{4}$ ), were purchased from Merck (Darmstadt, Germany).

The buffer solution used was $0.1 \mathrm{~mol} \mathrm{~L}^{-1}$ acetic acid-sodium acetate (HAc-NaAc) (Panreac, Barcelona, Spain).

$\mathrm{NH}_{3}(25 \%)$ and $\mathrm{HNO}_{3}(69 \%)$ were from Panreac.

Argon N50, 99.999\% purity, was used as a sheath gas for the atomizer and to purge internally.

All dilutions were performed with Milli-Q@ water (18 M $\Omega$ cm, Millipore Corporation, Bedford, MA, USA).

All glassware was kept in 10\% nitric acid for at least 48 hours and washed three times with ultrapure water before use.

\section{Sample Collection and Preparation}

Seawater samples were collected from the Arousa Estuary (Northwestern Spain) using a Niskin bottle. The samples were filtered through $0.45-\mu \mathrm{m}$ pure membrane

TABLE I

Graphite Furnace Conditions for V(IV) and V(V) Determination by ETAAS

\begin{tabular}{lrrrr}
\hline Step & $\begin{array}{c}\text { Temperature } \\
\left({ }^{\circ} \mathrm{C}\right)\end{array}$ & $\begin{array}{r}\text { Ramp Time } \\
(\mathrm{s})\end{array}$ & $\begin{array}{c}\text { Hold Time } \\
(\mathrm{s})\end{array}$ & $\begin{array}{c}\text { Ar Flow } \\
\left(\mathrm{mL} \mathrm{min}^{-1}\right)\end{array}$ \\
\hline Dry & 110 & 10 & 40 & 300 \\
Pyrolysis & $1500^{\mathrm{a}} / 1600^{\mathrm{b}}$ & 5 & $10^{\mathrm{a}} / 8^{\mathrm{b}}$ & 200 \\
Atomization & 2700 & 0 & 6 & 0 (read) \\
Cleaning & 2750 & 1 & 5 & 300 \\
\hline
\end{tabular}

${ }^{a} \mathrm{~V}(\mathrm{IV})$ determination in $\mathrm{HNO}_{3}$ media.

${ }^{\mathrm{b}} \mathrm{V}(\mathrm{V})$ determination in $\mathrm{NH}_{3}$ media.

Spectrometric parameters: lamp current, $40 \mathrm{~mA}$; injection volume, $20 \mu \mathrm{L}$; wavelength $(\lambda), 318.4 \mathrm{~nm}$; slit width, $0.7 \mathrm{~nm}$; background correction, $\mathrm{D}_{2}$ lamp. 
filters immediately after sampling and stored at $4^{\circ} \mathrm{C}$ in polyethylene bottles prior to analysis.

\section{Preparation of Chelating Resin}

Chelex-100 chelating ion exchange resin (sodium form) (Sigma-Aldrich, Sydney, Australia), with a particle size range of 50-100 mesh, was introduced into a PTFE column. To avoid loss of particles when the sample solution passes through the column, a small amount of quartz wool was placed at both ends of the column. The column was then connected to a peristaltic pump with PerkinElmer tubing.

Iminodiacetic chelating resin was converted to the $\mathrm{H}^{+}$form using the procedure described previously by Pesavento et al. (19). First, the resin was washed with ultrapure water and converted to the hydrogen form using a column procedure by passing 10 bed volumes of $0.1 \mathrm{M}$
$\mathrm{HCl}$. The column was then washed with ultrapure water and conditioned to $\mathrm{pH} 4.5$ using $5 \mathrm{~mL}$ HAc: $\mathrm{NaAc}(0.1 \mathrm{M})$ as a buffer solution.

\section{On-line Preconcentration and Separation Procedure}

Separation and preconcentration of the vanadium species from seawater samples was performed using a conditioned Chelex-100 column as described in the "Preparation of Chelating Resin" section. First, $50 \mathrm{~mL}$ of seawater sample or vanadium standard was loaded onto the column at a flow rate of $0.83 \mathrm{~mL}$ $\mathrm{min}^{-1}$. In the second step, $5 \mathrm{~mL}$ of $0.1 \mathrm{M}$ HAc:NaAc buffer solution ( $\mathrm{pH}=4.5)$ was passed through the column at $0.83 \mathrm{~mL} \mathrm{~min}^{-1}$. Afterwards, V(V) was eluted with $5 \mathrm{~mL}$ of $0.1 \mathrm{M} \mathrm{NH}_{3}$ at $0.83 \mathrm{~mL} \mathrm{~min}^{-1}$ and, finally, $8 \mathrm{~mL}$ of $0.1 \mathrm{M} \mathrm{HNO}_{3}$ at 0.83

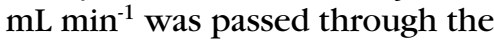
column to elute the V(IV) species. The vanadium concentration was determined in both fractions by

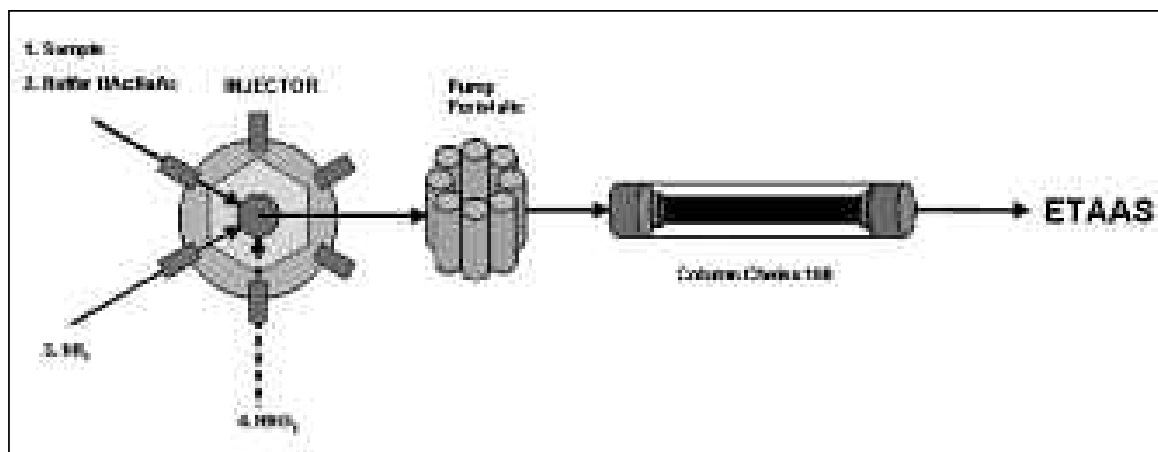

Fig. 1. Preconcentration and separation system.

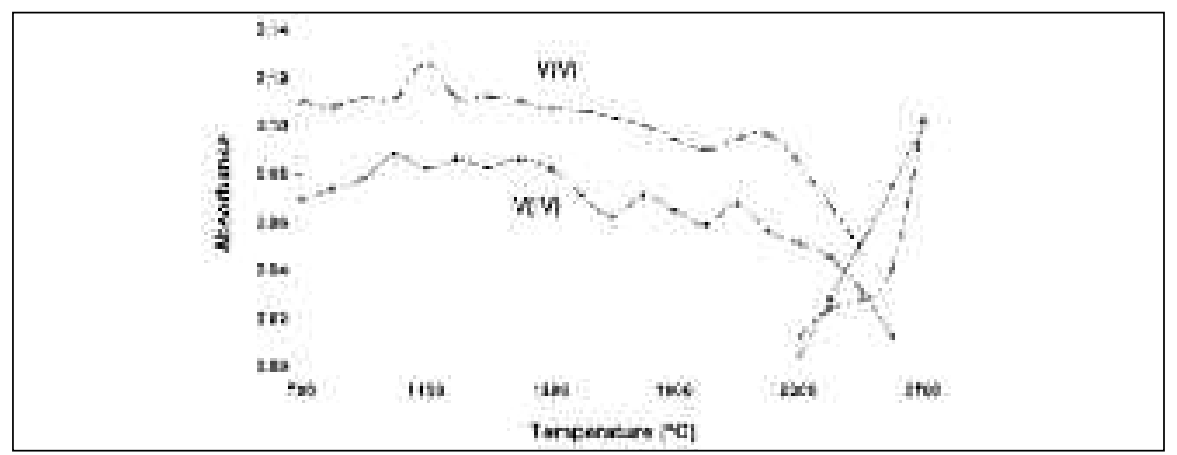

Fig. 2. Influence of the mineralization and atomization temperatures in the integrated absorbance signal for $V(I V)$ and $V(V)$ determination by ETAAS.

ETAAS using the instrumental conditions listed in Table I. The flow injection system for preconcentration and separation of the vanadium species is shown in Figure 1.

\section{RESULTS AND DISCUSSION}

The separation and preconcentration of V(IV) and V(V) from seawater samples was developed using a Chelex ${ }^{\circledR}-100$ column and $\mathrm{NH}_{3}$ and $\mathrm{HNO}_{3}$ as the eluting agents. The separated species were then determined by ETAAS. Therefore, the operating conditions for vanadium determination by ETAAS as well as the variables affecting the separation species were optimized.

\section{Optimization of Graphite Furnace Program for Vanadium Determination by ETAAS}

After the preconcentration step, the vanadium species on the Chelex-100 column were selectively eluted using $\mathrm{NH}_{3}$ [for $\mathrm{V}(\mathrm{V})$ ] or $\mathrm{HNO}_{3}$ [for V(IV)] as the eluting agent. The graphite furnace program was optimized using a solution of $50 \mu \mathrm{g} \mathrm{L}^{-1} \mathrm{~V}(\mathrm{~V})$ in $0.1 \mathrm{M}$ $\mathrm{NH}_{3}$ and $50 \mu \mathrm{g} \mathrm{L}^{-1} \mathrm{~V}(\mathrm{IV})$ in $0.1 \mathrm{M}$ $\mathrm{HNO}_{3}$. The influence of the mineralization temperature on the integrated absorbance was studied in the range of $500-2500{ }^{\circ} \mathrm{C}$ for both species. The results obtained for this experiment are shown in Figure 2 . The optimum mineralization temperatures were 1600 and $1700{ }^{\circ} \mathrm{C}$ for V(IV) and V(V), respectively.

Similarly, the atomization temperature was studied in the range of $1800-2700{ }^{\circ} \mathrm{C}$ (Figure 2). The latter temperature was selected as optimum for both species. Finally, the ramp and hold times for all steps of the graphite furnace program were optimized. The final graphite furnace conditions for V(IV) and V(V) determination by ETAAS are listed in Table I. 


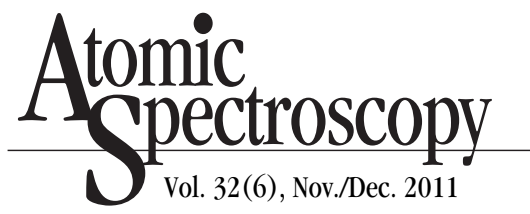

\section{Optimization of Separation Conditions}

Experiments were designed for the optimization of the vanadium separation procedure. The influence of different variables such as $\mathrm{pH}$, $\mathrm{NH}_{3}$, and $\mathrm{HNO}_{3}$ concentration, $\mathrm{NH}_{3}$ and $\mathrm{HNO}_{3}$ volumes, sample load flow rate and elution flow rate were investigated.

The first parameter studied was the $\mathrm{pH}$ of the sample. The influence of the $\mathrm{pH}$ in the retention of both species in the column was studied using a synthetic seawater sample spiked with $21.9 \mu \mathrm{g} \mathrm{L}^{-1}$ of either V(IV) or V(V). The pHs were selected based on studies previously developed by Soldi et al. (13) for vanadium speciation in water samples. Therefore, $50 \mathrm{~mL}$ of a seawater sample spiked with either V(IV) or $\mathrm{V}(\mathrm{V})$, at a $\mathrm{pH}$ between 2 and 7 (adjusted with $0.1 \mathrm{M}$ acetate buffer), was loaded onto the column at $10 \mathrm{rpm}$. Afterwards, the column was washed using $5 \mathrm{~mL}$ of $0.1 \mathrm{M}$ acetate buffer. Then, $\mathrm{V}(\mathrm{V})$ was eluted with $6 \mathrm{~mL}$ of $0.1 \mathrm{M} \mathrm{NH}_{3}$ at a flow rate of $0.83 \mathrm{~mL} \mathrm{~min}^{-1}$; V(IV) was eluted with $10 \mathrm{~mL}$ of $0.2 \mathrm{M} \mathrm{HNO}_{3}$ at the same flow rate. The results obtained (Figure 3) show that the retention of V(IV) increased up to $\mathrm{pH} 3$ and remained practically constant at higher $\mathrm{pHs}$. Nevertheless, the retention of V(V) increased up to $\mathrm{pH} 5$ and decreased at higher $\mathrm{pHs}$. Therefore, $\mathrm{pH} 5$ was selected in this study as a compromise condition.

Other parameters studied were the $\mathrm{NH}_{3}$ and $\mathrm{HNO}_{3}$ concentration used to elute V(V) and V(IV), respectively. The concentrations studied varied from 0.01 to $0.2 \mathrm{M}$ for $\mathrm{NH}_{3}$ and from 0 to $0.4 \mathrm{M}$ for $\mathrm{HNO}_{3}$. The volumes of $\mathrm{NH}_{3}$ and $\mathrm{HNO}_{3}$ used in this experiment were 6 and $10 \mathrm{~mL}$, respectively. The results obtained (Figure 4) show that the integrated absorbance signal increased for $\mathrm{V}(\mathrm{V})$ up to $0.1 \mathrm{M} \mathrm{NH}_{3}$ and then remained practically constant; therefore, this concentration was selected as the optimum concentration. Similar results were obtained for V(IV) by varying the $\mathrm{HNO}_{3}$ concentration; therefore, $0.1 \mathrm{M} \mathrm{HNO}_{3}$ was chosen as the optimum concentration.
The next step was to study the influence of the volume of the eluting agent in the separation procedure. Therefore, experiments were performed varying the $\mathrm{NH}_{3}$ volume from 4 to $10 \mathrm{~mL}$ and the $\mathrm{HNO}_{3}$ volume from 6 to $12 \mathrm{~mL}$. To compare the results obtained using the different volumes of $\mathrm{NH}_{3}$ and $\mathrm{HNO}_{3}$,

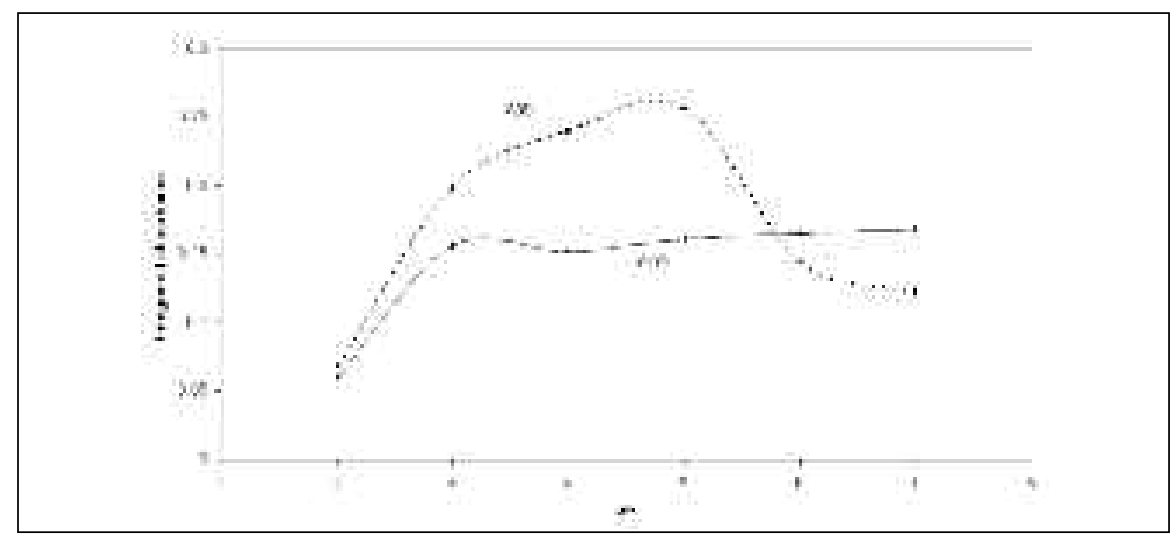

Figure 3. Influence of the pH of the sample.

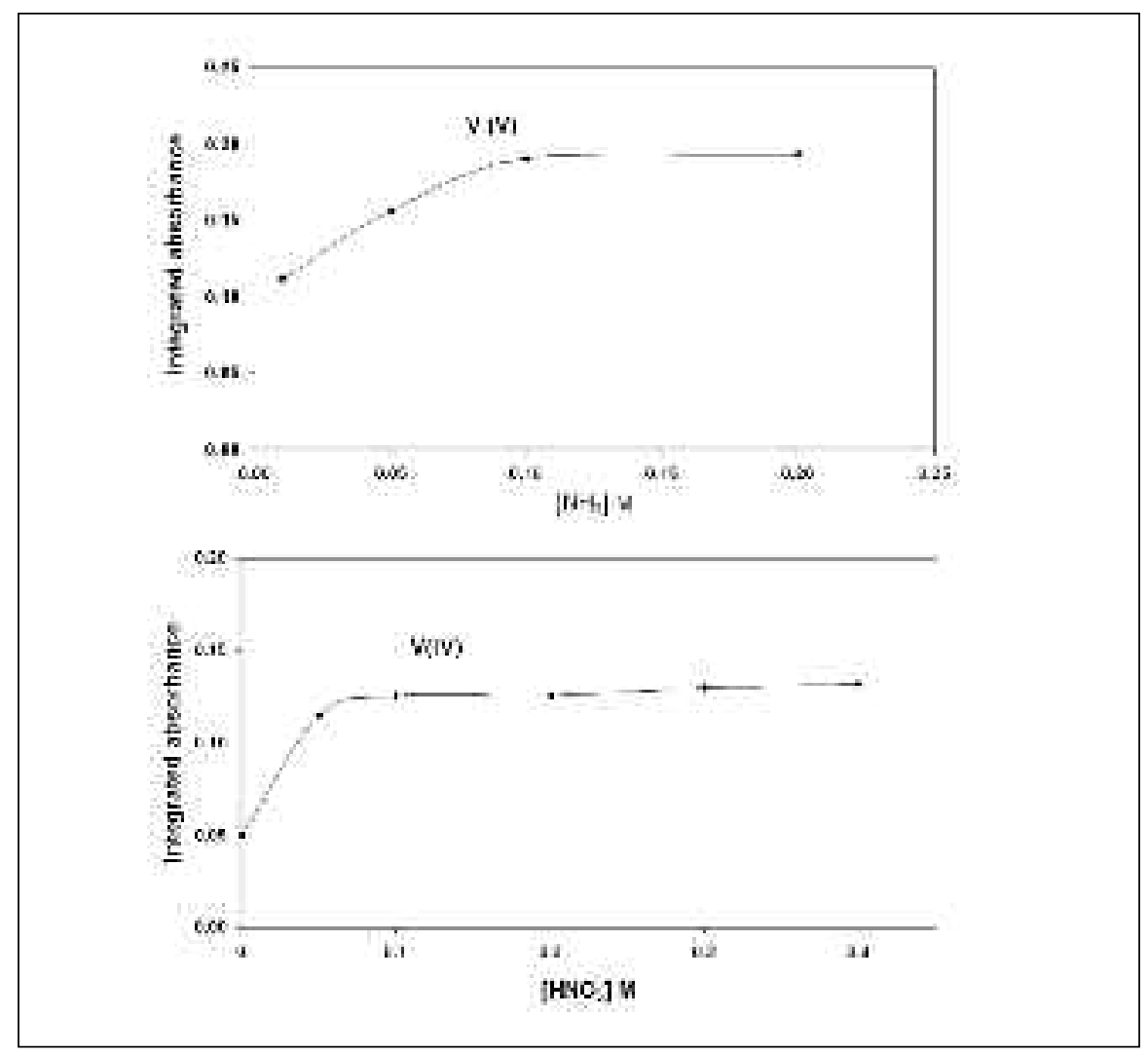

Figure 4. Influence of the concentration of eluting agent in the V(IV) and V(V) separation. 
the volume of each $\mathrm{NH}_{3}$ extract was filled up to $10 \mathrm{~mL}$ with $0.1 \mathrm{M} \mathrm{NH}_{3}$, and the volume of each $\mathrm{HNO}_{3}$ extract was filled up to $12 \mathrm{~mL}$ with $0.1 \mathrm{M} \mathrm{HNO}_{3}$. The volume of the extracting agent selected was $5 \mathrm{~mL}$ for $0.1 \mathrm{M} \mathrm{NH}$ and $8 \mathrm{~mL}$ for $0.1 \mathrm{M}$ $\mathrm{HNO}_{3}$.

Finally, the sample load flow rates and the eluting flow rates with $\mathrm{NH}_{3}$ and $\mathrm{HNO}_{3}$ were studied. The sample load flow rate was varied from 0.42 to $3.32 \mathrm{~mL} \mathrm{~min}^{-1}$, and $0.83 \mathrm{~mL} \mathrm{~min}^{-1}$ was the selected for this study. The influence of the eluting flow rate with $\mathrm{NH}_{3}$ and $\mathrm{HNO}_{3}$ was studied ranging from 0.42-1.66 $\mathrm{mL} \mathrm{min}^{-1}$. For both cases, the optimum flow rate chosen was $0.83 \mathrm{~mL} \mathrm{~min}^{-1}$.

\section{Analytical Characteristics}

Calibration graphs were measured using a synthetic seawater sample spiked with $0,5,7$, and $15 \mu \mathrm{g} \mathrm{L}^{-1}$ of both vanadium species. The solutions were subjected to the speciation procedure described in this work. The equations obtained were as follows:

$$
\begin{gathered}
\text { V(IV): } \begin{array}{c}
\mathrm{QA}=0.0026+0.0038 \mathrm{C} ; \\
\mathrm{r}=0.9988
\end{array} \\
\mathrm{~V}(\mathrm{~V}): \begin{array}{l}
\mathrm{QA}=0.0032+0.0062 \mathrm{C} ; \\
\mathrm{r}=0.9987
\end{array}
\end{gathered}
$$

Where QA is the integrated absorbance signal, $\mathrm{C}$ is the vanadium concentration in $\mu \mathrm{g} \mathrm{L}^{-1}$, and $r$ the linear regression coefficient.

Sensitivity was studied by means of two parameters: limit of detection (LOD) and limit of quantification (LOQ). Both the LOD and LOQ were calculated from 11 blank extract injections. The blank extracts of V(IV) and V(V), in $\mathrm{HNO}_{3}$ and $\mathrm{NH}_{3}$, respectively, were obtained by passing $50 \mathrm{~mL}$ of a synthetic seawater sample through the column.

The LOD is defined as $3 \times \mathrm{xD} / \mathrm{m}$, where SD is the standard deviation of the measurements of the blank and $\mathrm{m}$ is the calibration slope. The LOQ is defined as $10 \mathrm{xSD} / \mathrm{m}$.

The instrumental LOD obtained was $1.5 \mu \mathrm{g} \mathrm{L}^{-1}$ and the LOQ was $5 \mu \mathrm{g} \mathrm{L}^{-1}$ for $\mathrm{V}(\mathrm{IV})$, and $0.75 \mu \mathrm{g} \mathrm{L}^{-1}$ and $2.5 \mu \mathrm{gL}^{-1}$, respectively, for V(V). Taking into account the sample volume used, the LOD was $0.15 \mu \mathrm{g} \mathrm{L}^{-1}$ and the LOQ was $0.50 \mu \mathrm{g} \mathrm{L}^{-1}$ for $\mathrm{V}(\mathrm{IV})$, and $0.10 \mu \mathrm{g} \mathrm{L}^{-1}$ and $0.33 \mu \mathrm{g} \mathrm{L} \mathrm{L}^{-1}$, respectively, for $V(V)$. The LOD and LOQ in seawater samples were found to be better than the limit obtained by Hayati Filik et al. (16) of $1.6 \mu \mathrm{g} \mathrm{Kg}^{-1}$ for V(V). For groundwater, ZuLiang et al. (18) obtained $3 \mu \mathrm{mol} \mathrm{L} \mathrm{L}^{-1}$ for V(IV) and $1 \mu \mathrm{mol} \mathrm{L}^{-1}$ for V(V). However, the LODs obtained in this work were higher than the limits obtained by Shigeroni et al. (10) of $0.2 \mathrm{ng} \mathrm{L}^{-1}$ for $\mathrm{V}(\mathrm{V})$ determination in natural water by a catalytic method combined with solvent extraction and Chin-Chin Wann et al. (12) of $0.025 \mu \mathrm{g} \mathrm{L^{-1 }}$ for V(IV) and $0.041 \mu \mathrm{g} \mathrm{L}^{-1}$ for V(V) using HPLC-ICP-MS.

The main advantage of our method is the speed and low cost of the analysis. The LODs obtained in this work can also be improved by using a higher volume of sample.

The repeatability of the overall procedure was calculated using a synthetic seawater sample spiked with $7 \mu \mathrm{g} \mathrm{L}^{-1}$ of both species. Five portions of $50 \mathrm{~mL}$ of this sample were analyzed using the developed procedure. The RSDs obtained were $3.7 \%$ for V(IV) and $9.6 \%$ for $\mathrm{V}(\mathrm{V})$ which are values that are considered acceptable $(<10 \%)$.

TABLE II

Recovery Percentages for V(IV) and V(V) Determination

\begin{tabular}{clc}
\hline $\begin{array}{c}\text { Vanadium Conc. } \\
\left(\mu \mathrm{g} \mathrm{L}^{-1}\right)\end{array}$ & \multicolumn{2}{l}{ Recovery (\%) } \\
(IV) & (V) \\
\hline 5 & 96.8 & 93.0 \\
7 & 91.7 & 89.4 \\
15 & 97.2 & 94.5 \\
\hline
\end{tabular}

The accuracy of the method was studied using the recovery percentages. Therefore, a seawater sample was spiked with 5, 7, and $15 \mu \mathrm{g} \mathrm{L}^{-1}$ of both species and analyzed using this procedure. The results obtained are listed in Table II. The recovery percentages are between 91.7 and $97.2 \%$ for V(IV) and between 89.4 , and $94.5 \%$ for $\mathrm{V}(\mathrm{V})$, with mean values of $95.3 \pm 3 \%$ and $92.3 \pm 3 \%$ for V(IV) and V(V), respectively. The recovery percentages are around $100 \%$, thus the method is accurate.

\section{Determination of Vanadium Species in Seawater Samples}

The proposed method was applied to the determination of V(IV) and V(V) in seawater samples from the Arousa Estuary (Galicia, Northwestern Spain). The samples were collected using a Niskin bottle, filtered through $0.45-\mu \mathrm{m}$ membrane filters, and stored at $4{ }^{\circ} \mathrm{C}$ prior to analysis. The samples were collected in triplicate and analyzed in triplicate. The results in Table III show that the V(IV) concentrations were lower than the detection limits in the three samples studied. The V(V) concentrations varied from 0.1 to $0.3 \mu \mathrm{g} \mathrm{L}^{-1}$. These results agree with those obtained by Nakatsuka et al. (17) and Okamura et al. (11) for V(IV/V) determination in seawater samples who, however, only detected V(V) in the seawater samples analyzed.

TABLE III

Determination of V(IV) and V(V) in Seawater Samples From Ría de Arousa (Northwestern Spain)

\begin{tabular}{lcc}
\hline Location & $\begin{array}{c}\text { V(IV) } \\
\left(\mu \mathrm{g} \mathrm{L}^{-1}\right)\end{array}$ & $\begin{array}{c}\mathrm{V}(\mathrm{V}) \\
\left(\mu \mathrm{g} \mathrm{L}^{-1}\right)\end{array}$ \\
\hline $\begin{array}{l}\text { Pobra de } \\
\text { Caramiñal }\end{array}$ & <LOD & $0.25 \pm 0.01$ \\
Rianxo & <LOD & $0.19 \pm 0.03$ \\
$\begin{array}{l}\text { Vilagarcía } \\
\text { de Arousa }\end{array}$ & $<\mathrm{LOD}$ & $0.10 \pm 0.01$ \\
\hline
\end{tabular}




\section{CONCLUSION}

A simple, speedy, and low cost method for V(IV/V) determination in seawater samples was developed using a Chelex column and determination by electrothermal atomic absorption spectrometry (ETAAS). The method presents good precision [with RSDs of 3.7\% for V(IV) and $9.6 \%$ for $\mathrm{V}(\mathrm{V})]$ and adequate sensitivity for the vanadium concentration levels present in seawater samples. The LODs were $0.15 \mu \mathrm{g} \mathrm{L}^{-1}$ and $0.10 \mu \mathrm{g} \mathrm{L}^{-1}$ for V(IV) and $\mathrm{V}(\mathrm{V})$, respectively. The limits of detection (LODs) can be improved by increasing the sample volume used for the analysis.

\section{ACKNOWLEDGMENT}

The authors wish to thank Xunta de Galicia (Grupo de Referencia Competitiva 2007/000047-0) for financial support.

Received June 7, 2011.

\section{REFERENCES}

1. A. Wassem, M. Yaqoob, and A. Nabi, Anal. Sci. 26, 355 (2010).

2. W. Marouane, A. Soussi, J.C. Murat, S. Bezzine, and A. El Feki, Lipids in Health and Disease 10, 65 (2011).

3. C. Jeandel, M. Caisso, and J.F. Minster, Mar. Chem. 21, 51 (1987).

4. A.M. Shille and E.A. Boyle, Earth Planet Sci. Lett, 86, 214 (1987).

5. R. Prego, J. Santos-Echeandia, and A. Cobelo-García, Sci. Total. Environ. 399, 216, (2008).

6. E. Veschetti, D. Maresca, E. Ferretti, G. Citti, and M. Ottaviani, Microchem. J. 85, 80 (2007).

7. J.L. Domingo, M. Gomez, J.M. Liobet, J. Corbella, and C.L. Keen, Biol. Trace Elem. Res. 69, 249 (1991).

8. B. Patel, G.E. Henderson, S.J. Haswell, and R. Grzeskowiak, Analyst 115, 1063 (1990)

9. M.J.C. Taylor and J.F. van Stadem, Analyst 119, 1263 (1994).

10. S. Nakano, S. Kinoshita, M. Ikuta, and T. Kawashima, Anal. Sciences 6, 435 (1990).

\section{Atomic Spectroscopy \\ 1 Vol. 32(6), Nov./Dec. 2011}

11. K. Okamura, M. Sugiyama, H. Obata, M. Maruo, E. Nakayama, and $\mathrm{H}$. Karatani, Anal. Chim. Acta 443, 143 (2001).

12. Chia-Ching Wann and Shiuh-Jen Jiang, Anal. Chim. Acta 357, 211 (1997).

13. T. Soldi, M. Pasavento, and G. Alberti, Anal. Chim. Acta 323, 27 (1996)

14. D. Wang and S.A. Sañudo-Wilhelmy, Mar. Chem. 112, 72 (2008).

15. R.G. Wuilloud, J.C. Wuilloud, R.A Olsina, and L.D. Martinez, Analyst 126, 715 (2001).

16. H. Filik, K.I. Berker, N. Balkis, and R. Apak, Anal. Chim. Acta 518, 173 (2004).

17. I. Nukatsuka, Y. Shimizu, and K. Ohzeki, Anal. Sciences 18, 1009, (2002).

18. Z. Chen and R. Naidu, Anal. Bioanal. Chem. 374, 520 (2002).

19. M. Pesavento, R. Biesuz, M. Gallorini, and A. Profumo, Anal. Chem. 65, 2522 (1993). 